\title{
Exploration Of Alisher Navai's "Khamsa" With A Mind Map
}

\author{
${ }^{1}$ A.G.Ganiev, ${ }^{2}$ A.M.Mukhammadiyev, ${ }^{3}$ M.T.Nurbayeva \\ ${ }^{1}$ Candidate of Physical and Mathematical Sciences, Associate Professor, Director of Shakhrisabz branch of \\ Tashkent State Pedagogical University, Uzbekistan. \\ E-mail: fizika1011@mail.ru \\ ${ }^{2}$ Candidate of Philology, Associate Professor, Dean of the faculty Pedadogy of Shakhrisabz branch of Tashkent \\ State Pedagogical University, Uzbekistan. \\ E-mail: abdulahad-muhammad@mail.ru \\ ${ }^{3}$ Teacher of Uzbek language and literature in Shakhrisabz branch of Tashkent State Pedagogical University, \\ Uzbekistan. \\ E-mail: nurbayevamarvarid@gmail.ru
}

Article History: Received:11 January 2021; Accepted: 27 February 2021; Published online: 5 April 2021

\begin{abstract}
In this article the principles of developing students' imagination and creative thinking in education are discussed. Special emphasis is placed on the fact that people have different thinking abilities, intellectual abilities. The comments on creative thinking in the article are analyzed on the basis of the epics in the work "Khamsa" by the great thinker of Uzbek classical literature Alisher Navai.
\end{abstract}

Key words: Creative thinking, imagination, mind map, reader, "Khamsa", "Hayrat ul-abror", "Farhod and Shirin", "Layli and Majnun", "Sab'ai Sayyar", "Saddi Iskandariy”.

\section{Introduction}

The rapid development of science and technology requires new areas of production, and educational institutions need training qualified specialists in these areas. Their preparation and retraining costs a lot of money. If the specialist himself created new technologies, it would be possible to reduce costs and train specialists who would be able to meet the needs of new industries. What skills and qualifications need these specialists? They have to:

- Be able to define the most important information through the huge data flow and gain the relevant knowledge;

- Be able to use existing knowledge in new situations;

- They should be able to find solutions of problems and implement them in production.

Those who meet such requirements are called "creative thinkers" [Meyerovich, 2003: 12-19].

Creative thinking is taught in educational process.

"Creative thinking" is thinking in order to create something new to find a solution to a problem. Developing "Creative thinking” in educational process.

Creative thinking in educational process - thinking focused on understanding the meaning of the topic, encouraging students to develop imagination and "creative thinking". People's thinking abilities, that is, intellectual opportunities are different. What is the reason for this? Genetics (human biological nature) or environment and upbringing?

In general, the genetic code passed down from generation to generation plays an important role in the formation of the human intellect [Nemov, 2005: 56-62]. Our DNA is irreversible and unique, and only the first steps are being taken to change it.

The 2020 Nobel Prize in Chemistry was awarded to E. Sherpante and Dj for his discovery of modifying the DNA of living things and plants by modifying the genome. [Sultan Kazinform, 2020]. At the same time, scientists acknowledge the unique role of education in the formation of personality. According to them, the use of innovative teaching methods can improve students' thinking skills and improve their memory dozens of times. This means that while genetics plays an important role in a person's intellectual potential, the impact of the environment in which he or she grows up is also significant [Bono, 2005: 23].

What changes take place in the human brain during education? Neurobiologist and biochemist Erek Kandel (winner of the 2006 Nobel Prize) has shown that the brain's information "transmitter" (neuron fiber) changes during education. Even the smallest piece of information can change the structure of a neuron. [Kandel, 2012: 524]. 
Are people's brains the same or different? Each human brain is made up of the hippocampus, the pituitary gland, and the world's thinnest store of electrochemical knowledge, the cerebral cortex. Their functions in any brain are the same. So what is the individuality of each human brain? The cerebral cortex covers the right and left hemispheres of the brain. They control certain human activities. American neurophysiologist Sperry Roger won the semi-Nobel Prize in 1981 for his "discovery of the connection to the functional specialties of the cerebral hemispheres." The left hemisphere of the brain controls the right side of the body. It has developed logical thinking mechanisms.

The right hemisphere of the brain controls the left side of the body. It has a well-developed mechanism of figurative thinking, which creates non-standard ideas. In the human brain, the neurons that carry information open specific channels of movement. These canals are like "trails". There are no two people in the world who have the same "trails". Different parts of the human brain develop differently. No matter what we do or learn throughout our lives, it affects the shape and appearance of the neuronal fibers in our brains. In other words, it changes its "trails". There are many ways to develop creative thinking skills. Below we will get acquainted with one of the modern methods "Mind Map". "Mind map" is an analytical tool for finding solutions to any problem based on "creative thinking"[Byuzen, 2019: 25].

\section{Using mind maps on developing "Creative thinking” skills.}

Preferences of the mind map: Visualizing verbal information increases the effectiveness of teaching several times. In this sense, the Mind Map is an ideal tool for teaching 'creative thinking'. What it is useful for:

- clarifies the problem;

- organizes the information needed to plan the solution of the problem;

- helps to fully describe the situation;

- gives a visual view of verbal information;

- becomes a means of storing all the necessary information;

- Encourages unusual solutions;

- develops spatial intelligence.

While Mind Maps are a powerful tool for storing information in memory:

- develops "creative thinking" and expresses the process of thinking in an unusual way. Facilitates the emergence of new ideas and their integration;

- requires a focus on a specific topic to find the most optimal solution to the problem. This teaches concentration.

- Teaches to determine the main direction of the problem, without focusing on secondary issues.

Experiments shows that a mind map is the natural reflection of thought process that takes place in the brain of the human. In other words human thinks with the help of the mind map.

The Mind Map has the following three components:

1. Central image. It should reflect the topic being studied.

2. Thick branches protruding from the central image. These branches describe the main themes of the problem under study. In turn, the main branches are divided into branches that represent small branches.

3. Each branch must have one keyword or image. Because the word expresses this or that and leads to the emergence of new ideas.

When creating an "intelligence map", it is necessary to pay attention to the following:

Colour. Multicolor helps to improve memory and creative thinking. It enlivens the image and enhances its appeal. Helps keep data in memory for a long time.

Image. The brain perceives images faster than words. Because it processes visual information 60,000 times faster than verbal information. Imaging develops imagination and stimulates the right hemisphere of the brain to function actively.

The brain perceives information in the form of a "mind map" rather than in the form of text. According to R. Hober's experiment with "image recognition" in 1970, such human memory is in fact "photographic" memory. The average person can remember more than $98 \%$ of the 10,000 photos shown to him. As a result, a "mind map" of color images can be used as the best means of storing information in the brain.

The word. The words on the branches of the "Mind Map" are written separately. The point is that each word has its own connections. This in turn leads to the emergence of new ideas. Because the words in the following sections provide an interest in the content of the object and get to the heart of the matter. In other words, it acts as a loop for the brain and can be used to hang impressions.

So, creating a "mind map" leads to the development of imagination. This, in turn, activates the right hemisphere of the brain and improves "creative thinking" skills.

This leads to the widespread use of the "Intelligence Map" in education [Ganiev, 2020]. 


\section{Exploring Alisher Navoi's "Khamsa" with the help of "Mind Map".}

The Mind Map can be used to visualize information on any subject, including the social sciences. Below we consider the possibility of using an "intelligence map" in the study of Alisher Navoi's "Khamsa".

The Khamsa Mind Map can provide information about all the characters in the play. It also provides information about the characters' behavior, qualities, and deeds. Most importantly, the mind map encourages students to "imagine" the events described in the play and to "think creatively" about the plots involved. This is one of the most pressing issues in education today. Here's a few basic facts about a stomp pad and how it is used.

The characters in the first epic of "Khamsa" "Hayrat ul-abror" can be divided into three depending on their role in the development of issues, in the composition of the work:

1. The leading hero of the epic is Navai himself. From the beginning to the end of the work, the image of the poet is a constant companion of the reader.

2. Descriptive images in the makalats: tyrannical kings in the makalat "Kings", hypocritical sheikhs and villains in the article "Khirkapush sheikhs", foreign students in the makalat "Science space", ignorant officials in the story "Writers", the image of drunkards in the makalat "Durdkashs of Jakhl Mayi" and the image of selfish and arrogant officials in the makalat "Aspirants".

3. Epic characters in stories and parables: King Ghazi - a fair king (Navai portrays his friend Hussein Baykara); Khotam is generous; An old man is a patient and industrious man; Fakhriddin Razi is a scientist.

4. The second epic of "Khamsa" is a series of positive and negative images in the epic "Farkhad and Shirin":

\section{Positive heroes:}

Farkhad - a very humble, smart, intelligent, knowledgeable, professional, hardworking, creative Chinese prince, a perfect man.

Shirin - an educated, smart, chaste Armenian girl; perfect, intelligent, noble woman; a loyal, faithful beloved, a prudent coach, a just and wise statesman. Farhod's lover.

Mehinbonu - a patron of knowledge and enlightenment, a fair ruler (directs Farhod in digging canals), a kind woman. Shirin's aunt.

Shopur - a talented artist and tourist, a man of integrity and sincerity, unique in loyalty and friendship He does his best to make Farhod and Shirin reach each other.

Bahrom - a brave, courageous and just person. Farhod's childhood friend. When they came to Armenia in search of Farhod, Farhod and Shirin died. Bahrom is very sad about this. He liberates Armenia from Sheruya.

\section{Negative heroes:}

Khisraw is a selfish, cruel, ignorant, and greedy king of Iran. He tries to take over Armenia under the pretext of marrying Shirin, but his evil intentions do not come true. His son Sheruya is the cause of his death.

Sherua is the son of Khisrav, the ignorant, dishonest, vile, selfish, bureaucratic and evil prince of Iran. Sheruya kills her father under the guise of falling in love with Shirin. In fact, his goal was to seize his father's throne and conquer Armenia. But he can't achieve his goal. He could not withstand the just attack of Farhod's friend Bahrom and was ashamed.

The characters of the third epic of "Khamsa" "Leyli and Majnun" can be explained as follows:

\section{Positive heroes:}

Kays (Majnun) - the leading hero of the epic. He is a sincere lover, a talented poet and a noble man. The savage customs and rules of the day, selfish and violent people like Layli's father, threw stones of calamity at him and condemned him to tragic death.

Leyli - a very beautiful girl with both external and internal worlds. The head of a large tribe, the son of a wealthy family. Kay's schoolmate. She is a faithful beloved. Because of his love for Kays, she also dies. Leyli is an oppressed girl. It was not her will, but the surroundings violated her rights. She is a noble woman. She sincerely wants Kays to be happy. Even before her death, Leyli does not forget Kays. 
Navfal - a brave and noble man. He tasted the bitterness of life. While hunting in the steppe, he meets Kays. Kays tells him everything he wants to say. Navfal meets Leyli's father and tells him about Kays' pure love, but he is rejected by his ignorant father.

\section{Negative heroes:}

Leyli's father - a selfish, vile, arrogant, aggressive, and rude ruler. He sees his daughter Leyli as an object. He is a murderer! It causes Leyli to die in a time of youth, Kays to become a "Madman" and tragically die, and death of Kays' parents after failed to achieve their goals.

Ibn Salam - a dishonorable, ruthless, unjust man, a selfish false lover of pleasure. He is liked by Leyli's father because of his wealth. Ibn Salam, a drunkard, gets drunk on his wedding day, gets poisoned, is ashamed, and gets sick. Layla got rid of him.

The fourth epic of Alisher Navoi's "Khamsa" was called "Sab'ai Sayyar" and was written in 1484.

Here is a brief description of the heroes:

Bakhrom is the hero of the former story about Bakhrom and Dilorom in the epic. He is king and in love. Bakhrom is a complex image with a contradictory character. In this image, Navai portrays two opposing personalities: a just king and a loyal lover, and a glorious king and a selfish lover who is obsessed with his own pleasures and personal moods, and who is captivated by his own passions, detached from the affairs of the people and the affairs of state. When Bakhrom ascended the throne for the first time, he ruled the country with justice, made it prosperous and made the people happy, but he soon succumbed to luxury, hunting, and surrendered his senses to passion and passion. It is because of this madness that the earth swallows him.

Dilorom - unmatched in beauty. He is a very talented artist; a woman with a noble heart, a pure character, a faithful companion. But Dilorom is captive and gloomy. As a child, she was taken prisoner by the war between two khans in China. This captive is sold to the ruler, a merchant. The Barren ruler first adopts him as a child, but after the number of Dilorom's admirer's increased, he wants to sell her for a lot of money. Finally, the Chinese king sold her to Bakhrom for a year's rent.

Moniy - an artist. He meets Bakhrom on a hunt, seeing a picture of Dilorom in his hands Bakhrom falls in love with Dilorom

A chinese merchant adopted Dilorom, as a child, grew her, and eventually sold her to Bakhrom as a concubine for a large sum of money.

The last epic of Hamsa is Saddi Iskandariy. This work is dedicated to Alexander, one of the greatest figures in the world, the most famous of the three masters, and is the concluding epic of "Khamsa".

Alexandr - the ideal king of justice and enlightenment. He is a king and a scholar. The epic tells of Alexander's birth, his youth, his education, the death of Faylaqus and Alexander's accession to the throne, Alexander's confrontation with Darius, his conquest of Iran and justice there, his march to Kashmir to defeat the tyrant Mallu, and the King of India and the King of China. , The war against the savages in the Maghreb, the construction of a dam to block the way of Gog and Magog in the land of Qirwan, and the voyage formed the basis of Alexander's adventures.

The image of the Scholars in Saddi Iskandari. Nicomachean (father of Aristotle- Nicomachean) was Alexander's coach and mentor. Aristotle, Plato, Socrates, Askilinus, Hippocrates, Hermes, and Pythagoras.

At the end of the epic, words from seven scholars improve the content of the epic: Aristotle (Aristotle), a gentle and kind king; rejoice in the grace of the army, prosper the people in justice - Philotine - Plato (Plato); the struggle for the peace of the nation - Socrates; the policy of cruelty to the wicked - Buqrot (Hippocrates); mouth, word, heart and pure eyes - Faysogurs (Pythagoras); to be generous and generous - Hurmus (Hermes), to be kind and fair - Asqalinus (Iskilinus).

Bonu - a gentle and kind mother, a prudent and experienced statesman and an intelligent scientist. He is deeply saddened by the death of his lovely son Alexandr. Continuing the work of Alexander, he rules Rome with justice.

Lubati Chin - a girl of unparalleled courage. When Alexander's army did not dare to fight the savage leader alone in the West, the masked Lubati Chin entered the arena, defeating the savage leader with courage, agility, and strength, thus saving Alexander's army from defeat and disgrace. 


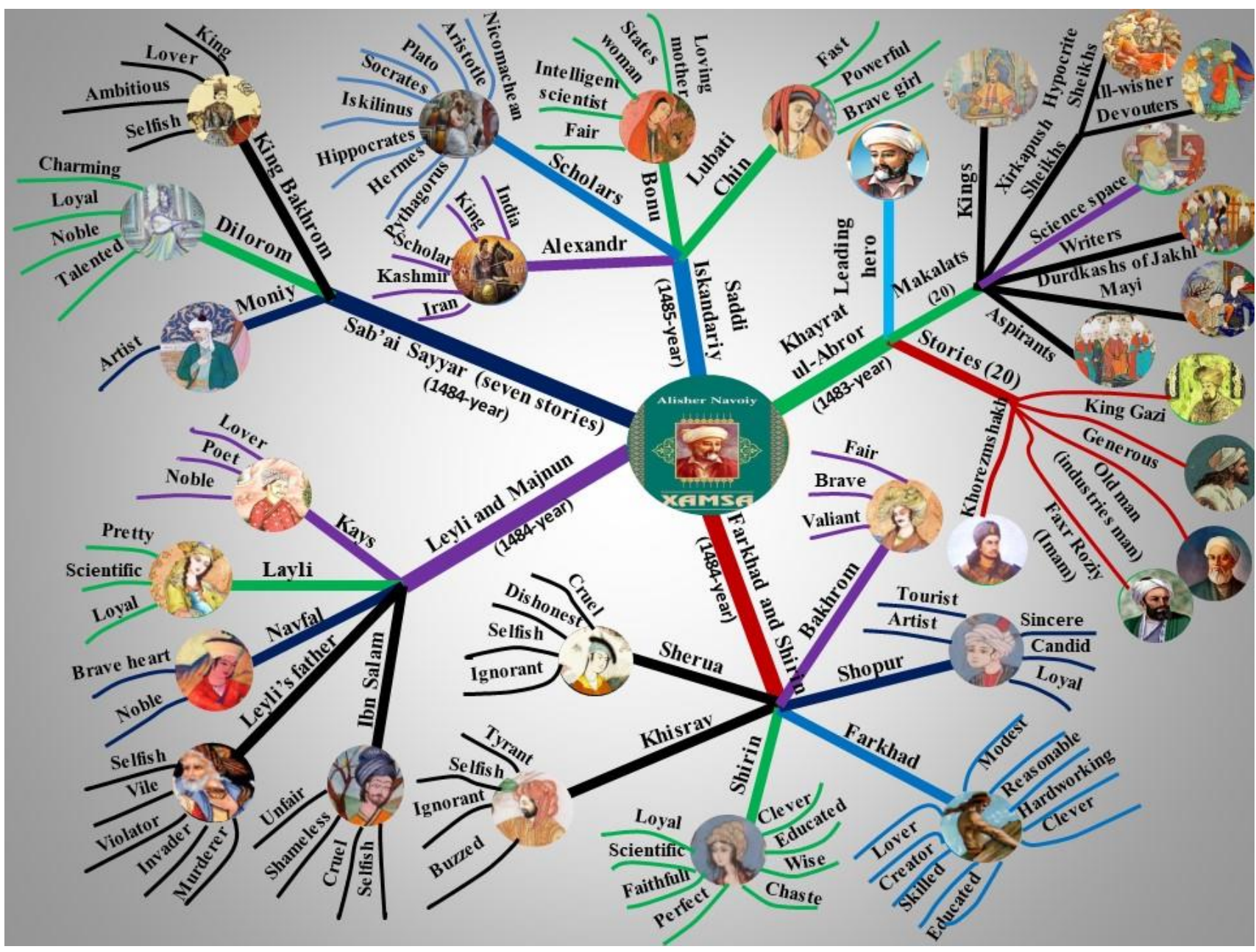

\section{Conclusion}

- The rapid changes taking place in science and technology today require the training of creative, that is, professionals with "creative thinking" skills in line with these changes.

- "Creative thinking" skills can be developed in the educational process, and it can be developed in the process of teaching science to all students.

- New methods, including data visualization, are available in education to accomplish this task. One such effective method is the Mind Map.

- For the first time in the article, Alisher Navai's "Khamsa" "Mind Map" is published. The Mind Map is a visual representation of the vast amount of information presented in Khamsa.

- The "Mind map" not only provides practical assistance in memorizing the events and works in the work, but also encourages students to "imagine" and think about the events in the work: this can be a factor in the development of students' "creative thinking" skills.

\section{References}

1. A.G.Ganiev, S.X.Normurodova, Z.Sh.Abdunazarova, A.Xudoyberdiyeva. European Journal of Molecular \& Clinical Medicine, ISSN 2515-8260, Volume 7, Issue 11, 2020. "Using Mind maps in formation of Imagination and Creative thinking skills in 5-6 years old children." (pp.339-343);

2. A.G.Ganiev, S.N.Tashev. PSYCHOLOGY AND EDUCATION. (2021) 58(1), ISSN: 00333077; "The role of "Imagination" in the process of "Creative thinking". Developing students" "Imagination" and "Creative thinking" skills in teaching Physics" (pp.3569-3575);

3. Bono de Edward. Serious creative thinking. Minsk LLC "Popourri", 2015 (pp.20-80);

4. T. Busen "Mind Maps" Moscow. "Mann. Ivanov and Ferver "2019, pp. 25-90;

5. E.R. Kandel. In Search of Memory / translated by P. Petrov-M. Astrel. 2012. 736 p.;

6. M.I. Meerovich, L.I. Shragina Technology of creative thinking. HARVEST. Minsk. 2003, (pp.12-19);

7. R.S. Nemov Psychology. Book 3. Moscow. VLADOS 2005 (pp. 56-62).

8. Nobel laureates on chemistry Nur-Sultan in 2020. Kazinform 2020; 
9. Alisher Navai. A complete collection of works. Volume 10: Volume 6. - Tashkent: G. Gulom, 2011. $808 \mathrm{p}$.

10. Alisher Navai. A complete collection of works. Volume 10: Volume 7. - Tashkent: G. Gulom, 2011. - $696 \mathrm{p}$.

11. Alisher Navai. A complete collection of works. Volume 10: Volume 8. - Tashkent: G. Gulom, 2011. $712 \mathrm{p}$.

12. Alisher Navai. Khayratul-abror. A perfect collection of works. Twenty roofs, first roof. - Tashkent: Fan, 1983. - $527 \mathrm{p}$

13. Alisher Navai. Khayratul-abror. A perfect collection of works. Twenty volumes, seventh volume. Tashkent: Fan, 1991. - 390 p.

14. Alisher Navai. Farkhad and Shirin. A perfect collection of works. Twenty volumes, eighth volume. Tashkent: Fan, 1992.

15. Alisher Navai. Layli and Majnun. A perfect collection of works. Twenty volumes, ninth volume. Tashkent: Fan, 1992.

16. Alisher Navai. Sab'ai sayyor. A perfect collection of works. Twenty volumes, tenth volume. Tashkent: Fan, 1992.

17. Alisher Navai. Saddi Iskandariy. A perfect collection of works. Twenty volumes, eleventh volume. Tashkent: Fan, 1992.

18. Alisher Navai. Mahbub ul-qulub. A perfect collection of works. Twenty volumes, fourteen volumes. Tashkent: Fan, 1998. - 238 p.

19. Annotated dictionary of the language of Alisher Navai's works, four volumes (volumes I, II, III, IV). Fozilov E.I. under editing. - Tashkent: Fan, 1983. (Ps.656; 644; 624; 636) 